\title{
Identification of volatiles from six marine Celeribacter strains
}

\author{
Anuj Kumar Chhalodia ${ }^{1}$, Jan Rinkel ${ }^{1}$, Dorota Konvalinkova ${ }^{1}$, Jörn Petersen ${ }^{2}$ \\ and Jeroen S. Dickschat ${ }^{* 1}$
}

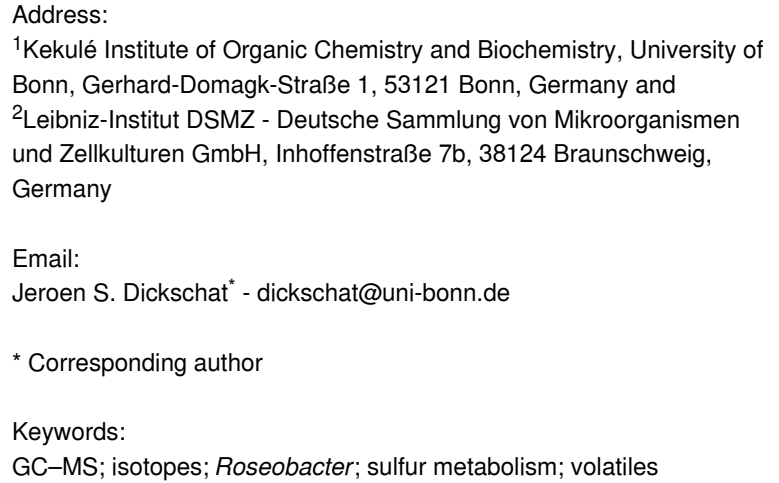

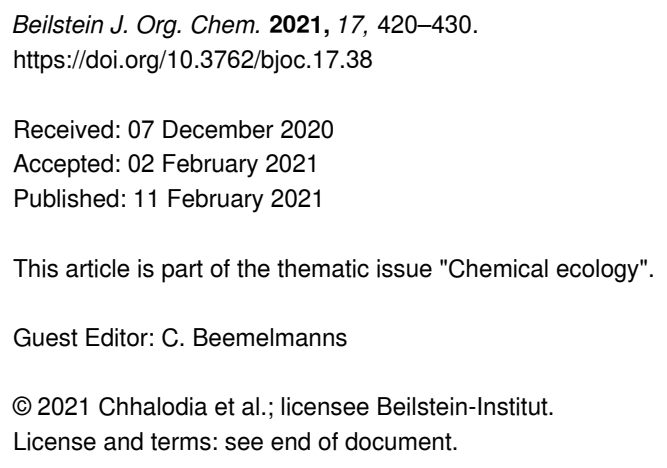

\begin{abstract}
The volatiles emitted from six marine Rhodobacteraceae species of the genus Celeribacter were investigated by GC-MS. Besides several known compounds including dimethyl trisulfide and $S$-methyl methanethiosulfonate, the sulfur-containing compounds ethyl (E)-3-(methylsulfanyl)acrylate and 2-(methyldisulfanyl)benzothiazole were identified and their structures were verified by synthesis. Feeding experiments with $\left[\right.$ methyl $\left.-{ }^{2} \mathrm{H}_{3}\right]$ methionine, $\left[\right.$ methyl $\left.-{ }^{13} \mathrm{C}\right]$ methionine and $\left[{ }^{34} \mathrm{~S}\right]-3$-(dimethylsulfonio)propanoate (DMSP) resulted in the high incorporation into dimethyl trisulfide and $S$-methyl methanethiosulfonate, and revealed the origin of the methylsulfanyl group of 2-(methyldisulfanyl)benzothiazole from methionine or DMSP, while the biosynthetic origin of the benzothiazol2 -ylsulfanyl portion could not be traced. The heterocyclic moiety of this compound is likely of anthropogenic origin, because 2-mercaptobenzothiazole is used in the sulfur vulcanization of rubber. Also in none of the feeding experiments incorporation into ethyl (E)-3-(methylsulfanyl)acrylate could be observed, questioning its bacterial origin. Our results demonstrate that the Celeribacter strains are capable of methionine and DMSP degradation to widespread sulfur volatiles, but the analysis of trace compounds in natural samples must be taken with care.
\end{abstract}

\section{Introduction}

Bacteria from the roseobacter group belong to the most abundant microbial species in marine ecosystems [1,2]. They are present from polar to tropical regions, in marine sediments, in estuarine and open ocean environments in different pelagic zones ranging from surface waters to depths of $>2,000 \mathrm{~m}[3,4]$. Some species are associated with other marine organisms, e.g.,
Thalassococcus halodurans DSM $26915^{\mathrm{T}}$ has been isolated from the marine sponge Halichondria panicea [5], and Phaeobacter gallaeciensis DSM $26640^{\mathrm{T}}$ is an isolate from the scallop Pecten maximus [6]. Important interactions are also observed between bacteria from the roseobacter group and various types of marine algae, e.g., the first described organisms 
Roseobacter litoralis DSM $6996^{\mathrm{T}}$ and $R$. denitrificans DSM $7001^{\mathrm{T}}$ were obtained from seaweed [7], while Dinoroseobacter shibae DSM $16493^{\mathrm{T}}$ and Marinovum algicola DSM $10251^{\mathrm{T}}$ are both isolates from the dinoflagellate Prorocentrum lima $[8,9]$. Especially in algal blooms bacteria of the roseobacter group are highly abundant [10], and here they belong to the main players involved in the enzymatic degradation of the algal sulfur metabolite 3-(dimethylsulfonio)propanoate (DMSP, Scheme 1) [11]. Its catabolism leads either through the demethylation pathway by action of the enzymes DmdABCD to methanethiol (MeSH, Scheme 1A) [12] or through lysis by DddD [13] or hydrolytic cleavage by one of the known DMSP lyases (DddW [14], DddP [15], DddQ [16], DddL [17], DddY [18] or DddK [19]) to dimethyl sulfide (DMS, Scheme 1B).

It has already been pointed out in the 1970s and 1980s that atmospheric DMS is important for the global sulfur cycle [20] and influences the climate on Earth, known as CLAW hypoth- esis according to the authors' initials (Carlson, Lovelock, Andreae, Warren) [21], which underpins the relevance of this algal-bacterial interaction. Isotopic labeling experiments demonstrated that also in laboratory cultures roseobacter group bacteria efficiently degrade DMSP into sulfur volatiles [22,23], but also from other sulfur sources including 2,3-dihydroxypropane-1-sulfonic acid (DHPS, Scheme 1C) labeling was efficiently incorporated into sulfur volatiles [24,25]. Notably, DHPS is produced in large quantities by the marine diatom Thalassiosira pseudonana [26], and diatoms from this genus live in symbiotic relationship with bacteria of the roseobacter group [27]. Another interesting aspect of sulfur metabolism in marine bacteria from the roseobacter group is the production of the sulfur-containing antibiotic tropodithietic acid (TDA) in Phaeobacter piscinae DSM $103509^{\mathrm{T}}$ [28], a compound that is in equilibrium with its tautomer thiotropocin [29] that was first described from Pseudomonas sp. CB-104 [30]. Its biosynthesis depends on the clustered $t d a$ genes [31] and has been studied by

A)<smiles>C[S+](C)CCC(=O)[O-]</smiles>

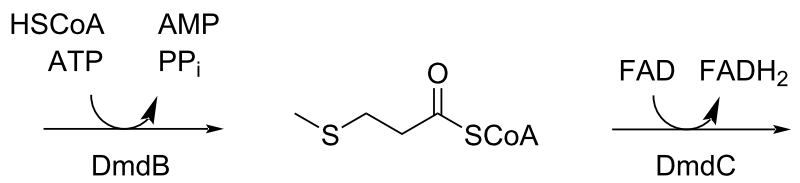<smiles>COS(=O)(=O)C(=O)/C=C/SC</smiles>

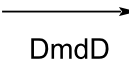

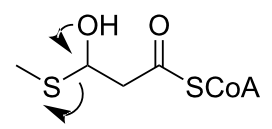

B)<smiles>O=C(O)CCO</smiles>

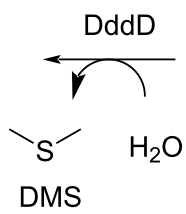<smiles>C[S+](C)CCC(=O)[O-]</smiles>

C)<smiles>O=S(=O)(O)CC(O)CO</smiles>

DHPS<smiles>O=C(O)c1c(=O)cccc2ssc12</smiles>

TDA<smiles>C=C</smiles><smiles>CC1CC1[Hg]S</smiles><smiles>O=CCC(=O)OCCO</smiles>

$$
\begin{aligned}
& \text { DddW } \\
& \text { DddP } \\
& \text { DddQ } \\
& \text { DddL } \\
& \text { DddY } \\
& \text { DddK } \\
& \stackrel{\text { DMS }}{\longrightarrow}
\end{aligned}
$$<smiles>C=CC(=O)O</smiles><smiles>O=c1osc2c(=S)cccc(O)c12</smiles>

thiotropocin

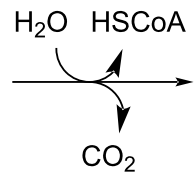<smiles>CC=O</smiles>

Scheme 1: Sulfur metabolism in bacteria from the roseobacter group. A) DMSP demethylation by DmdABCD, B) DMSP hydrolysis by DddP and lysis by DddW, DddP, DddQ, DddL, DddY or DddK, and C) structures of DHPS and sulfur-containing secondary metabolites. 
feeding experiments with labeled precursors to the wildtype and gene knockout strains of $P$. inhibens DSM $17395^{\mathrm{T}}$, demonstrating the formation of TDA from phenylalanine through phenylacetyl-CoA and the phenylacetyl-CoA catabolon [32,33]. These experiments also led to a suggestion for the mechanism for sulfur incorporation, but further research is required for a deep understanding of TDA biosynthesis. Besides its function as an antibiotic, TDA acts as a signaling molecule, similar to $\mathrm{N}$-acylhomoserine lactones, at concentrations 100 times lower than required for a significant antibiotic activity [34]. The biosynthesis of tropone [35] and of the algicidal sulfur-containing roseobacticides [36] are most likely connected to the TDA pathway. Interestingly, in the interaction with marine algae $P$. inhibens can change its lifestyle from a symbiotic relationship during which the antibiotic TDA and growth stimulants are produced to a pathogenic interaction promoted by lignin degradation products in fading algal blooms that induce roseobacticide biosynthesis [36]. All these examples demonstrate the importance of sulfur metabolism for marine bacteria from the roseobacter group. Here we report on the volatiles emitted by six Celeribacter species with a special focus on sulfur volatiles. The results from feeding studies with labeled precursors demonstrate that the Celeribacter strains can form sulfur volatiles from methionine and DMSP, but also showed that some of the detected sulfur compounds are not or only partly of bacterial origin.

\section{Results and Discussion Headspace analysis}

The volatiles released by six marine Celeribacter type strains, including C. marinus DSM $100036^{\mathrm{T}}$, C. neptunius DSM $26471^{\mathrm{T}}$, C. manganoxidans DSM $27541^{\mathrm{T}}$, C. baekdonensis DSM $27375^{\mathrm{T}}, C$. halophilus DSM $26270^{\mathrm{T}}$ and $C$. indicus DSM $27257^{\mathrm{T}}$, were collected through a closed-loop stripping apparatus (CLSA) on charcoal [37]. After extraction with dichloromethane the obtained extracts were analyzed by GC-MS (Figure 1). The compounds were identified by the comparison of the recorded EI mass spectra to library spectra and of retention indices [38] to tabulated literature data (Table 1), or by a direct comparison to authentic standards. The structures of the identified compounds are shown in Figure 2.

While the headspace extracts from C. marinus, C. neptunius and C. manganoxidans were particularly rich, the extracts from C. baekdonensis, C. halophilus and C. indicus contained fewer compounds. Most of the observed volatiles are well known $[56,57]$ and were thus readily identified from their mass spectra and retention indices. Pyrazines including methylpyrazine (1), 2,5-dimethylpyrazine (2) and trimethylpyrazine (3) were present in the extracts from all six strains. Notably, also several $\alpha$-hydroxyketones that have been described as biosynthetic pre- cursors to pyrazines [40], represented by 3-hydroxypentan-2one (4), 2-hydroxypentan-3-one (5) and 2-hydroxyhexan-3-one (6), were observed in some of the investigated strains. A series of aldehydes ranging from hexanal (7) to tetradecanal (13) was found in strain specific patterns, with all identified compounds present in the bouquet from $C$. manganoxidans. A similar series of $\gamma$-lactones spanning from pentan-4-olide (14) to dodecan-4olide (20), in addition to 3-methylbutan-4-olide (21) and 4-methylhex-5-en-4-olide (22), was detected in strain-specific patterns, with almost all of these compounds present in C. marinus; only C. halophilus did not emit lactones. Furans included furan-2-ylmethanol (23), furfural (24), and 2-acetylfuran (25). Cyclohexanol (26) was observed only once in C. marinus, and aromatic compounds included benzyl alcohol (27), benzaldehyde (28) and salicylaldehyde (29), acetophenone (30) and $o$-aminoacetophenone (31), 2-phenylethanol (32), and phenylacetone (33). 6-Methylhept-5-en-2-one (34) was detected in all strains, while its saturated analog 6-methylheptan-2-one (35) was only emitted by $C$. baekdonensis and geranylacetone (36) only by the three productive species C. marinus, C. neptunius, and C. manganoxidans. Compounds $\mathbf{3 4}$ and $\mathbf{3 6}$ have been described as non-enzymatic degradation products arising from the side chain in menaquinones [58]. Sulfur-containing compounds included dimethyl trisulfide (37), released by all six species, $S$-methyl methanethiosulfonate (38), 2 -acetylthiazole (39), and benzothiazole (40), the latter also in the extracts from all six strains. In addition, the extracts from the three species $C$. marinus, $C$. neptunius and C. baekdonensis contained an additional volatile (41) whose mass spectrum (Figure 3A) was not included in our libraries. Furthermore, ethyl 3-(methylsulfanyl)acrylate (42) was found in C. marinus and $C$. manganoxidans, but the measured retention index ( $I=1177$ ) did not allow to distinguish between the $E$ and the $Z$ isomer for which retention indices of $I=1144(E)$ and $I=1158$ $(Z)$ were reported [53]. Therefore, for an unambiguous structural assignment for compounds $\mathbf{4 1}$ and $\mathbf{4 2}$ the synthesis of reference compounds was required.

\section{Synthesis of reference compounds}

The mass spectrum of the component $\mathbf{4 1}$ showed strong similarities to the library mass spectrum of 2-mercaptobenzothiazole that has a molecular weight of $167 \mathrm{Da}$. The isotope pattern of the molecular ion at $\mathrm{m} / \mathrm{z}=213$ indicated the presence of three sulfur atoms. The strong base peak at $m / z=167$ in the mass spectrum of 41 suggested a benzothiazol-2-ylsulfanyl moiety, while the mass difference to the molecular ion pointed to the connection to a methylsulfanyl group. Taken together, this analysis resulted in the structural proposal of 2-(methyldisulfanyl)benzothiazole for $\mathbf{4 1}$. For the structural verification a synthesis was performed by a $\mathrm{BF}_{3}$. $\mathrm{OEt}_{2}$-catalyzed reaction of bis(benzothiazol-2-yl)disulfane with dimethyl disulfide, giving 
A)

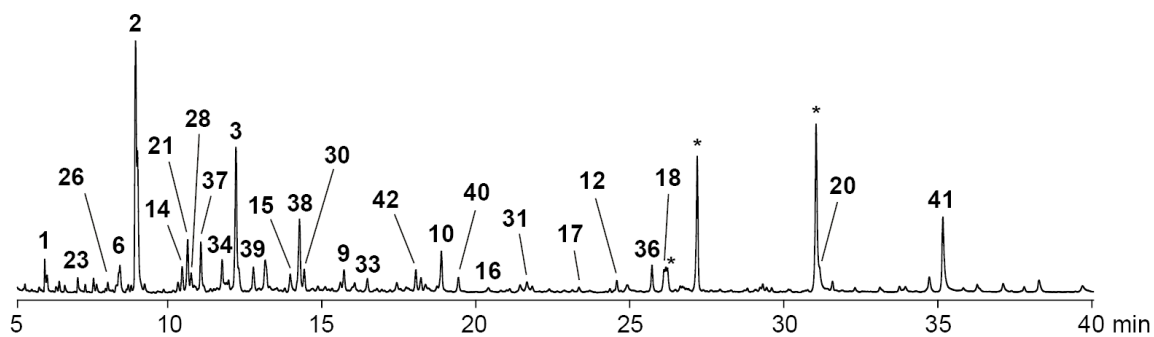

B)

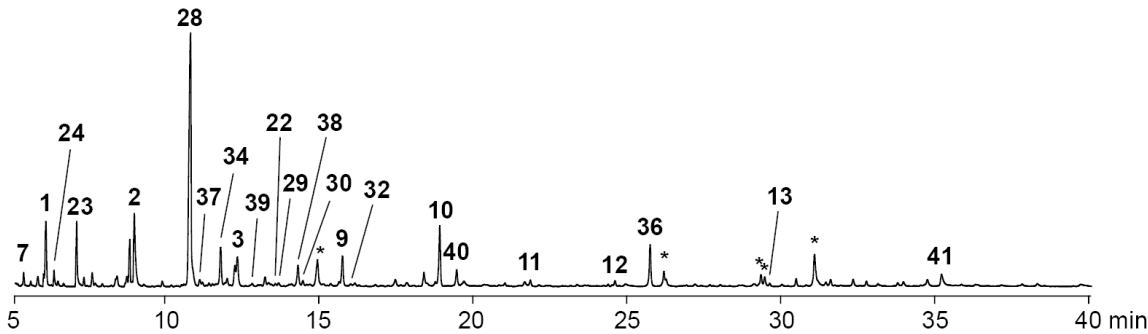

C)

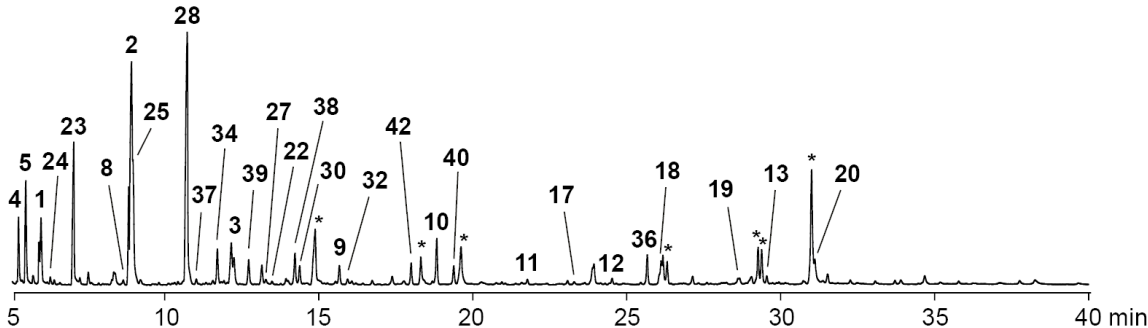

D)

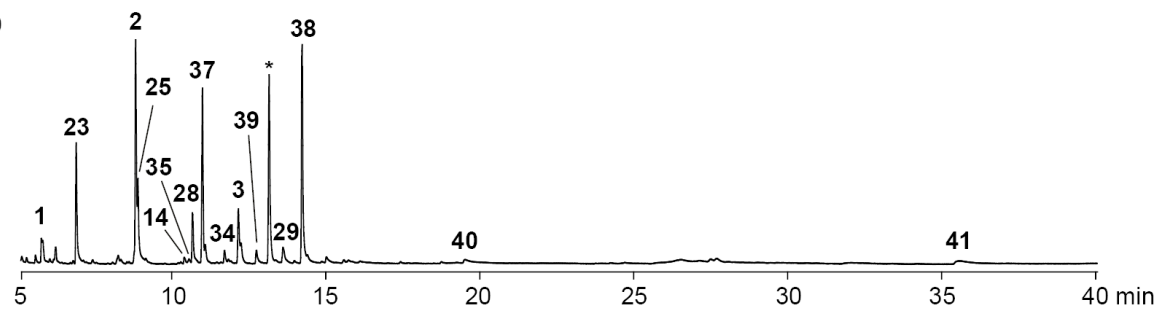

E)
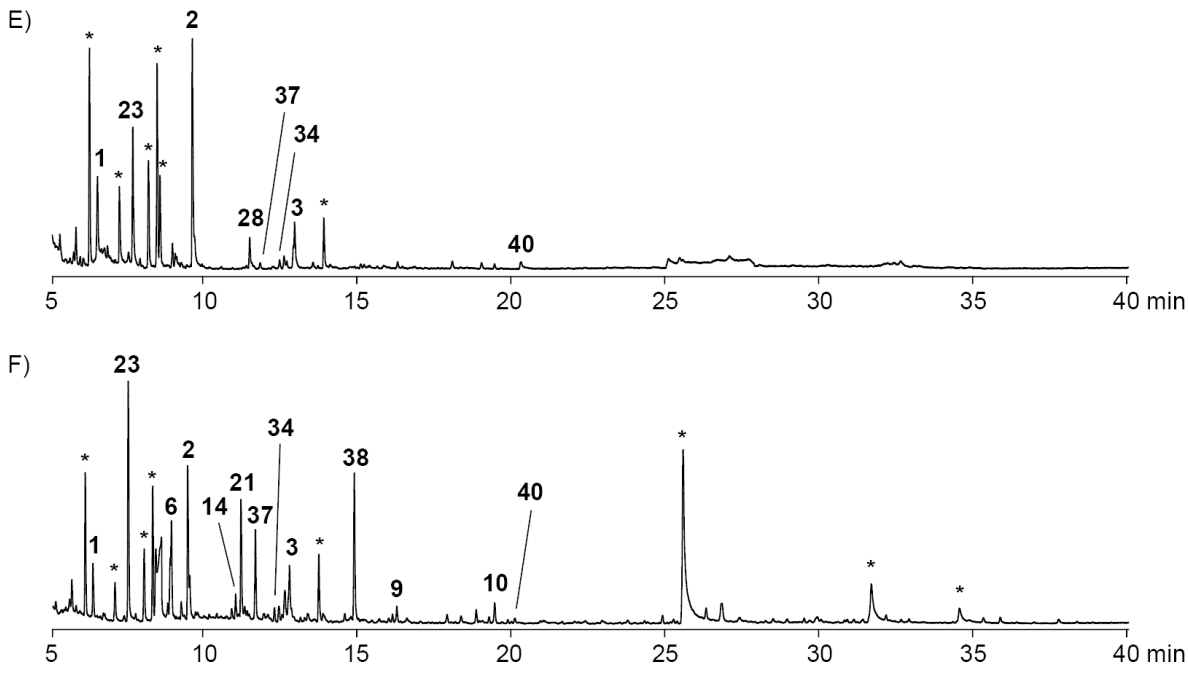

Figure 1: Total ion chromatograms of headspace extracts from A) C. marinus DSM $100036^{\top}$, B) C. neptunius DSM $26471^{\top}$, C) C. manganoxidans DSM $27541^{\top}$, D) C. baekdonensis DSM $27375^{\top}$, E) C. halophilus DSM $26270^{\top}$, and F) C. indicus DSM $27257^{\top}$. Peaks arising from known contaminants are indicated by asterisks. 
Table 1: Volatiles from Celeribacter spp.

\begin{tabular}{|c|c|c|c|c|c|c|c|c|c|}
\hline Compound $^{\mathrm{a}}$ & $l^{\mathrm{b}}$ & $I(\text { lit. })^{b}$ & Id. ${ }^{C}$ & & ren & & & & \\
\hline 3-hydroxypentan-2-one (4) & 812 & 815 [39] & ri, ms & & & C & & & \\
\hline hexanal $(7)$ & 813 & 806 [39] & ri, ms & & $\mathrm{B}$ & & & & \\
\hline 2-hydroxypentan-3-one (5) & 818 & $818[40]$ & ri, ms & & & C & & & \\
\hline methylpyrazine (1) & 831 & $826[41]$ & ri, ms & A & $B$ & C & $\mathrm{D}$ & $\mathrm{E}$ & $\mathrm{F}$ \\
\hline furfural (24) & 841 & 841 [42] & ri, ms & & B & C & & & \\
\hline furan-2-ylmethanol (23) & 861 & 863 [43] & ri, ms & $A$ & $\mathrm{~B}$ & C & $\mathrm{D}$ & $\mathrm{E}$ & $\mathrm{F}$ \\
\hline cyclohexanol (26) & 888 & $886[44]$ & ri, ms & A & & & & & \\
\hline 2-hydroxyhexan-3-one (6) & 899 & $900[40]$ & ri, ms & A & & & & & $\mathrm{F}$ \\
\hline heptanal (8) & 906 & $901[45]$ & ri, ms & & & C & & & \\
\hline 2,5-dimethylpyrazine (2) & 912 & $908[45]$ & $\mathrm{ri}, \mathrm{ms}$ & A & B & C & $\mathrm{D}$ & E & $\mathrm{F}$ \\
\hline 2-acetylfuran (25) & 913 & 909 [45] & ri, ms & & & C & $\mathrm{D}$ & & \\
\hline pentan-4-olide (14) & 953 & $956[46]$ & ri, ms & A & & & $\mathrm{D}$ & & $\mathrm{F}$ \\
\hline 3-methylbutan-4-olide (21) & 957 & $958[47]$ & $\mathrm{ri}, \mathrm{ms}$ & A & & & & & $\mathrm{F}$ \\
\hline 6-methylheptan-2-one (35) & 959 & $962[48]$ & ri, ms & & & & $\mathrm{D}$ & & \\
\hline benzaldehyde (28) & 961 & $952[45]$ & ri, ms & A & B & C & $\mathrm{D}$ & $\mathrm{E}$ & \\
\hline dimethyl trisulfide (37) & 970 & 968 [49] & ri, ms & $A$ & B & C & $\mathrm{D}$ & $\mathrm{E}$ & $\mathrm{F}$ \\
\hline 6-methylhept-5-en-2-one (34) & 988 & $981[45]$ & ri, ms & A & $\mathrm{B}$ & C & $\mathrm{D}$ & $E$ & $\mathrm{~F}$ \\
\hline trimethylpyrazine (3) & 1000 & $1000[45]$ & ri, ms & A & B & C & $\mathrm{D}$ & $\mathrm{E}$ & $\mathrm{F}$ \\
\hline 2-acetylthiazole (39) & 1017 & $1014[45]$ & ri, ms & A & $\mathrm{B}$ & C & $\mathrm{D}$ & & \\
\hline benzyl alcohol (27) & 1033 & $1026[45]$ & $\mathrm{ri}, \mathrm{ms}$ & & & C & & & \\
\hline 4-methylhex-5-en-4-olide (22) & 1039 & $1034[45]$ & ri, ms & & B & C & & & \\
\hline salicylaldehyde (29) & 1042 & $1039[45]$ & ri, ms & & $\mathrm{B}$ & & $\mathrm{D}$ & & \\
\hline hexan-4-olide (15) & 1052 & $1056[50]$ & $\mathrm{ri}, \mathrm{ms}$ & A & & & & & \\
\hline$S$-methyl methanethiosulfonate (38) & 1061 & $1068[51]$ & ri, ms & A & $\mathrm{B}$ & C & $\mathrm{D}$ & & $\mathrm{F}$ \\
\hline acetophenone $(\mathbf{3 0})$ & 1065 & 1059 [45] & ri, ms & A & B & C & & & \\
\hline nonanal (9) & 1103 & $1100[45]$ & ri, ms & A & $\mathrm{B}$ & C & & & $\mathrm{F}$ \\
\hline 2-phenylethanol (32) & 1111 & $1106[45]$ & ri, ms & & $\mathrm{B}$ & C & & & \\
\hline phenylacetone (33) & 1127 & 1124 [52] & ri, ms & A & & & & & \\
\hline ethyl (E)-3-(methylsulfanyl)acrylate (42) & 1177 & $1144[53]$ & $\mathrm{ms}$ & A & & C & & & \\
\hline decanal (10) & 1203 & $1201[45]$ & ri, ms & A & B & C & & & $\mathrm{F}$ \\
\hline benzothiazole (40) & 1221 & $1222[54]$ & ri, ms & A & $\mathrm{B}$ & C & $\mathrm{D}$ & $\mathrm{E}$ & $\mathrm{F}$ \\
\hline octan-4-olide (16) & 1252 & $1250[45]$ & ri, ms & A & & & & & \\
\hline o-aminoacetophenone (31) & 1292 & $1296[55]$ & ri, ms & A & & & & & \\
\hline undecanal (11) & 1298 & $1305[45]$ & ri, ms & & $\mathrm{B}$ & C & & & \\
\hline nonan-4-olide (17) & 1354 & $1358[45]$ & $\mathrm{ri}, \mathrm{ms}$ & A & & C & & & \\
\hline dodecanal (12) & 1400 & $1408[45]$ & ri, ms & A & B & C & & & \\
\hline geranylacetone (36) & 1445 & $1453[45]$ & ri, ms & A & $\mathrm{B}$ & C & & & \\
\hline decan-4-olide (18) & 1461 & $1465[45]$ & $\mathrm{ri}, \mathrm{ms}$ & A & & C & & & \\
\hline undecan-4-olide (19) & 1568 & $1569[45]$ & ri, ms & & & C & & & \\
\hline tetradecanal (13) & 1605 & $1611[45]$ & ri, ms & & $\mathrm{B}$ & C & & & \\
\hline dodecan-4-olide $(20)$ & 1673 & $1676[45]$ & ri, ms & $A$ & & C & & & \\
\hline 2-(methyldisulfanyl)benzothiazole (41) & 1860 & & std & A & $\mathrm{B}$ & & $\mathrm{D}$ & & \\
\hline
\end{tabular}

aldentified by GC-MS, known typical contaminants such as plasticizers are not included and all listed compounds were not detected in blank runs

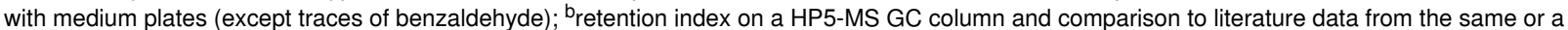
similar type of GC column; Cidentification based on ri: matching retention index (difference between measured retention index and literature data $\leq 10$ points), ms: mass spectrum matching to a database spectrum, std: direct comparison to an authentic standard; ${ }^{d}$ occurrence in A: $C$. marinus DSM $100036^{\top}$, B: C. neptunius DSM $26471^{\top}$, C: C. manganoxidans DSM $27541^{\top}$, D: C. baekdonensis DSM $27375^{\top}$, E: C. halophilus DSM $26270^{\top}$, and F: C. indicus DSM $27257^{\top}$. 
<smiles>[R]c1ncc(C)nc1[R]</smiles>

$1\left(R^{1}=R^{2}=H\right)$

$2\left(R^{1}=M e, R^{2}=H\right)$

$3\left(R^{1}=R^{2}=M e\right)$<smiles>OCc1ccco1</smiles>

23<smiles>OCCc1ccccc1</smiles>

32<smiles>CSSSC</smiles>

37<smiles>[R]C(=O)C([R])O</smiles>

$4\left(R^{1}=M e, R^{2}=E t\right)$ $5\left(R^{1}=E t, R^{2}=M e\right)$ $6\left(R^{1}=\operatorname{Pr}, R^{2}=M e\right)$<smiles>CCCCC(C)(C)C=O</smiles>

$7(n=1)$

$8(n=2)$

$9(n=4)$

$10(n=5)$

$11(n=6)$

$12(n=7)$

$13(n=9)$<smiles>OC1CCCCC1</smiles>

26

$$
24(\mathrm{R}=\mathrm{H})
$$$$
25(\mathrm{R}=\mathrm{Me})
$$<smiles>CC(=O)Cc1ccccc1</smiles>

33<smiles>CC(=O)CCC=C(C)C</smiles>

$34\left(\Delta^{5}\right)$

35<smiles>CC(C)([18OH])C1CCC(=O)O1</smiles>

$14(n=1)$

$15(n=2)$

$16(n=4)$

$17(n=5)$

$18(n=6)$

$19(n=7)$

$20(n=8)$<smiles>CC1COC(=O)C1</smiles>

21

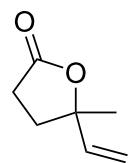

22<smiles>OCc1ccccc1</smiles>

27<smiles>[R]c1ccccc1C=O</smiles>

$28(\mathrm{R}=\mathrm{H})$ $29(\mathrm{R}=\mathrm{OH})$<smiles>[R]c1ccccc1C(C)=O</smiles>

$30(\mathrm{R}=\mathrm{H})$<smiles>CC(=O)CC/C=C(\C)CCC=C(C)C</smiles>

36<smiles>CC(=O)c1nccs1</smiles>

39<smiles>[R]c1nc2ccccc2s1</smiles>

$40(\mathrm{R}=\mathrm{H})$

$41(\mathrm{R}=\mathrm{SSMe})$<smiles>CCOC(=O)/C=C/SC</smiles>

42

Figure 2: Structures of the identified volatile compounds in the headspace extracts from six Celeribacter type strains.

A)

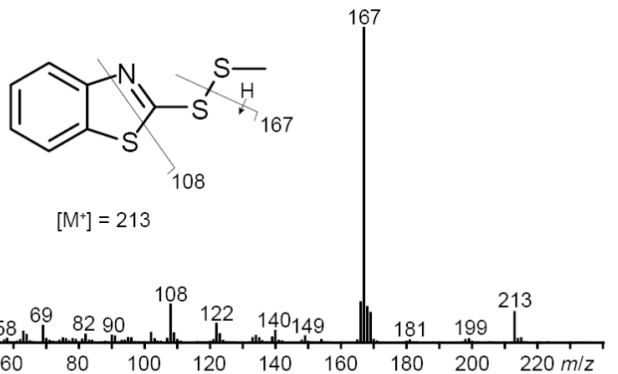

C)<smiles>CSC(C)Sc1nc2ccccc2s1</smiles>

$\left[\mathrm{M}^{+}\right]=214$

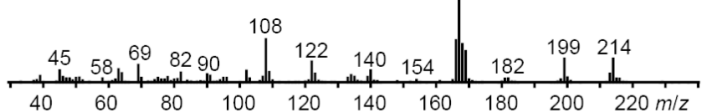

B)<smiles>CSSc1nc2ccccc2s1</smiles>
$\left[\mathrm{M}^{+}\right]=216$

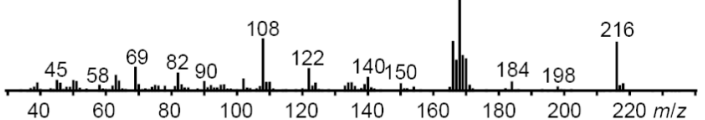

D)

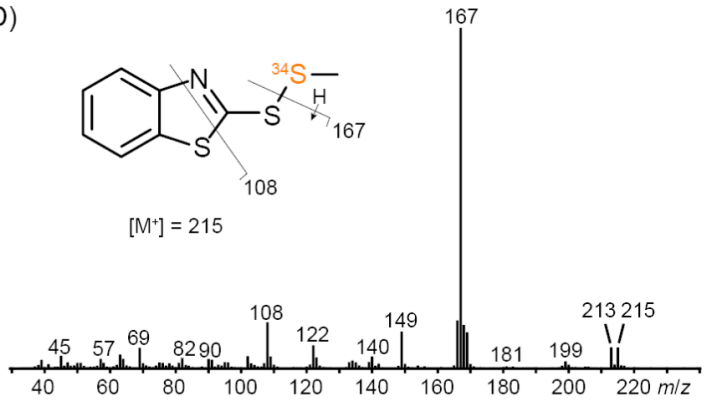

Figure 3: El mass spectra of A) unlabeled 2-(methyldisulfanyl)benzothiazole (41) and of labeled 41 after feeding of $\mathrm{B})\left(\right.$ methyl- $\left.^{2} \mathrm{H}_{3}\right)$ methionine, C) (methyl- $\left.{ }^{13} \mathrm{C}\right)$ methionine and D) $\left({ }^{34} \mathrm{~S}\right) \mathrm{DMSP}$. 
access to 41 with a yield of $64 \%$ (Scheme 2). The synthetic compound $\mathbf{4 1}$ showed an identical mass spectrum and retention index compared to the volatile in the Celeribacter extracts. The $Z$ and $E$ stereoisomers of $\mathbf{4 2}$ were obtained by the Michael addition of NaSMe to ethyl propiolate (45), yielding a mixture of stereoisomers inseparable by silica gel column chromatography (92\%). The major stereoisomer was found to be (Z)-42 (dr 94:6), whose preferred formation may be a result of a chalcogen-chalcogen interaction between the sulfur and an ester oxygen. This phenomenon was first described in supramolecular structures by Gleiter [59] and later also used to explain the outcome of organocatalytic reactions [60]. The pure stereoisomers of $\mathbf{4 2}$ were isolated by preparative HPLC, for which the best separation was achieved using a YMC ChiralART Cellulose-SC column. This yielded $70 \%$ of $(Z)-\mathbf{4 2}$ and $6 \%$ of $(E)-\mathbf{4 2}$, and their analysis by GC-MS showed retention indices of $I=1177$ for $(E)-\mathbf{4 2}$ and $I=1200$ for $(Z)-\mathbf{4 2}$, revealing that the compound in the headspace extracts of $C$. marinus DSM $100036^{\mathrm{T}}$ and C. manganoxidans DSM $27541^{\mathrm{T}}$ was identical to (E)-42.

\section{Feeding experiments with isotopically labeled precursors}

The biosynthesis of sulfur volatiles in $C$. marinus was investigated in a series of feeding experiments with isotopically labeled precursors. Feeding of $\left(\right.$ methyl $\left.-{ }^{2} \mathrm{H}_{3}\right)$ methionine resulted in the efficient incorporation of labeling into 37 (79\% incorporation rate, Figure S1B in Supporting Information File 1), 38 (78\%, Figure S1F in Supporting Information File 1) and the $S$-methyl group of $\mathbf{4 1}(84 \%)$, as indicated by a shift of the molecular ion from $\mathrm{m} / \mathrm{z}=213$ to 216 (Figure 3B, deuterated compounds can be separated from their non-deuterated analogs by gas chromatography [61]). The base peak appears at $\mathrm{m} / \mathrm{z}=168$, demonstrating its formation with participation of one deuterium from the $S$-methyl group. Analogous results were obtained by feeding of (methyl $-{ }^{13} \mathrm{C}$ )methionine, showing incorporation into 37 (74\%, Figure S1C in Supporting Information File 1), 38 (71\%, Figure S1G in Supporting Information), and the MeS group of $41(71 \%$, Figure 3C; the signal at $\mathrm{m} / \mathrm{z}=213$ represents unlabeled $\mathbf{4 1}$ that, in contrast to a deuterated compound, cannot be separated from ${ }^{13} \mathrm{C}$-labeled $\mathbf{4 1}$ by gas chromatography). Furthermore, feeding of $\left[{ }^{34} \mathrm{~S}\right] \mathrm{DMSP}$ gave an incorporation into the MeS groups of 37 (50\%, Figure S1D), into both sulfur atoms of 38 (47\%, Figure S1H in Supporting Information File 1), but only into one sulfur atom of $\mathbf{4 1}(46 \%)$, as indicated by the molecular ion at $\mathrm{m} / \mathrm{z}=215$, while no signals at $\mathrm{m} / \mathrm{z}=217$ and 219 were visible that would account for the incorporation of labeling into two or three of the sulfur atoms in 41 (Figure 3D; also here the signal at $\mathrm{m} / \mathrm{z}=213$ represents inseparable unlabeled 41). In this experiment, the base peak did not change which allowed the localization of labeling specifically in the MeS group of $\mathbf{4 1}$.

The fact that no incorporation was observed for the other two sulfur atoms of $\mathbf{4 1}$ prompted us to further investigate the biosynthetic origin of the benzothiazol-2-ylsulfanyl portion of 41 to establish its natural origin. Several feeding experiments with central primary metabolites including $\left({ }^{13} \mathrm{C}_{6}\right)$ glucose, $\left({ }^{13} \mathrm{C}_{5}\right)$ ribose and (indole $\left.-{ }^{2} \mathrm{H}_{5}\right)$ tryptophan were performed, but none of these experiments resulted in a detectable incorporation of labeling. Conclusively, a non-biological origin of this part of the molecule seems likely, which may also explain why the detection of $\mathbf{4 1}$ in Celeribacter was not always reproducible. Notably, 2-mercaptobenzothiazole is used in the sulfur vulcanization of rubber and could react spontaneously with MeSH of bacterial origin in the presence of oxygen to form 41, giving a reasonable explanation for its formation.

Also none of the feeding experiments with the various labeled precursors resulted in an incorporation of labeling into the

A)<smiles>CSSSCc1nc2ccccc2s1</smiles>

43
44

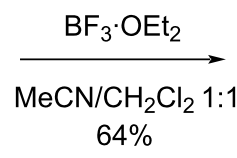

$64 \%$

B)<smiles>C#CC(=O)OCC</smiles>

45

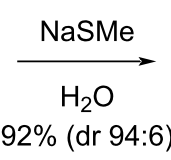

$\%(d r 94: 6)$<smiles>CCOC(=O)/C=C\SC</smiles>

(Z)-42 $70 \%$ (after HPLC)<smiles>CCOC(=O)/C=C/SC</smiles>

$(E)-42$

$6 \%$ (after HPLC) 
sulfur volatiles $\mathbf{3 9}, \mathbf{4 0}$, and $\mathbf{4 2}$, which also questioned their natural origin. This finding is rather surprising for $\mathbf{4 2}$, especially regarding the feeding experiment with $\left({ }^{34} \mathrm{~S}\right) \mathrm{DMSP}$, because its formation would be explainable by a DMSP degradation through the demethylation pathway, for which all relevant enzymes are encoded in the six Celeribacter strains (only a DmdA homolog is missing in C. indicus, Table S1 in Supporting Information File 1), and e.g., transesterification of the DmdC product with EtOH (Scheme 1A). Compound 42 is not a widespread sulfur volatile, but has been reported before from pineapples [53], pears [62], passion fruits [63], and apples [64].

\section{Conclusion}

Six marine Celeribacter strains were investigated for their volatiles, leading to the identification of 42 compounds from different classes, including several sulfur volatiles. However, feeding experiments with isotopically labeled precursors suggested that only the widespread compounds dimethyl trisulfide (37) and $S$-methyl methanethiosulfonate (38) are of natural origin, while no labeling from any of the fed precursors was incorporated into 2-acetylthiazole (39), benzothiazole (40), and ethyl (E)-3(methylsulfanyl)acrylate (42), thus questioning their natural source from Celeribacter. These results demonstrate that the six Celeribacter strains are able to degrade methionine and DMSP with formation of $\mathrm{MeSH}$ as a source for the likely non-enzymatic oxidation in the presence of air to $\mathbf{3 7}$ and $\mathbf{3 8}$, opening possibilities for future studies on methionine and DMSP degrading enzymes and pathways in Celeribacter. Our study also shows that the results from trace compound analyses must be taken with care and contaminations from other sources must always be taken into consideration. For the unusual compound 2-(methyldisulfanyl)benzothiazole (41) the incorporation of labeling was observed only into the MeS group, while the benzothiazol-2-ylsulfanyl portion is likely of anthropogenic origin from the rubber vulcanization agent 2-mercaptobenzothiazole that reacts with $\mathrm{MeSH}$ from the bacterial metabolism.

\section{Experimental}

\section{Strains, culture conditions, and feeding experiments}

All six Celeribacter type strains were cultivated at $28{ }^{\circ} \mathrm{C}$ on marine broth agar plates. In case of feeding experiments, the isotopically labeled compound ( $1 \mathrm{mM})$ was added to the agar medium before inoculation.

\section{Collection of volatiles}

The volatiles emitted by Celeribacter spp. agar plate cultures were collected on charcoal filters (Chromtech, Idstein, Germany, precision charcoal filters charged with $5 \mathrm{mg}$ of charcoal) by use of a closed-loop stripping apparatus as developed by Grob and Zürcher [37]. After a collection time of $24 \mathrm{~h}$ the charcoal was extracted with $\mathrm{CH}_{2} \mathrm{Cl}_{2}(50 \mu \mathrm{L})$ and the extract was analyzed by GC-MS.

\section{GC-MS}

GC-MS analyses were carried out through a 7890B GC 5977A MD system (Agilent, Santa Clara, CA, USA). The GC was equipped with a HP5-MS fused silica capillary column (30 m, $0.25 \mathrm{~mm}$ i.d., $0.50 \mu \mathrm{m}$ film) and operated with the settings 1) inlet pressure: $77.1 \mathrm{kPa}$, He flow: $23.3 \mathrm{~mL} \mathrm{~min}^{-1}$, 2) injection volume: $2 \mu \mathrm{L}, 3$ ) splitless injection, 4) temperature program: $5 \mathrm{~min}$ isothermic at $50{ }^{\circ} \mathrm{C}$, then increasing with $5{ }^{\circ} \mathrm{C} \min ^{-1}$ to $320{ }^{\circ} \mathrm{C}$, and 5) He carrier gas flow: $1.2 \mathrm{~mL} \mathrm{~min}{ }^{-1}$. The parameters of the MS were 1) transfer line temperature: $250{ }^{\circ} \mathrm{C}, 2$ ) ion source temperature: $230{ }^{\circ} \mathrm{C}$, 3) quadrupole temperature: $150{ }^{\circ} \mathrm{C}$, and 4) electron energy: $70 \mathrm{eV}$. Retention indices were calculated from retention times in comparison to those of a homologous series of $n$-alkanes $\left(\mathrm{C}_{7}-\mathrm{C}_{40}\right)$.

\section{General synthetic and analytical methods}

Reactions were carried out in oven-dried flasks under Ar atmosphere and using distilled and dried solvents. Chemicals were obtained from Sigma-Aldrich (St. Louis, USA). Column chromatography was performed on silica gel $(0.04-0.06 \mathrm{~nm})$ purchased from Acros Organics (Geel, Belgium) with distilled solvents. NMR spectroscopy was performed on a Bruker (Billerica, USA) Avance III HD Ascend (500 MHz) spectrometer. Solvent peaks were used for referencing $\left({ }^{1} \mathrm{H}\right.$ NMR: $\mathrm{CDCl}_{3}$ residual proton signal $\delta=7.26 \mathrm{ppm},{ }^{13} \mathrm{C} \mathrm{NMR:} \mathrm{CDCl}_{3} \delta=$ $77.16 \mathrm{ppm}$ ) [65]. Multiplicities are indicated by s (singlet) and $\mathrm{d}$ (doublet), coupling constants $J$ are given in Hz. IR spectra were recorded on a Bruker $\alpha$ spectrometer equipped with a diamondATR probe, and qualitative signal intensities are reported by $w$ (weak), m (medium), and s (strong). HPLC purification of compound 42 was performed on an Azura HPLC system (Knauer, Berlin, Germany) equipped with a UV-vis detector MWL 2.1L (deuterium lamp, 190-700 nm) and a YMC ChiralART Cellulose-SC column $(5 \mu \mathrm{m} ; 250 \times 20 \mathrm{~mm})$ with a guard column of the same type $(30 \times 20 \mathrm{~mm})$. The elution was performed with hexane/propanol 60:40 (isocratic) at a flow rate of $10 \mathrm{~mL} \mathrm{~min}^{-1}$ (36 bar). The UV-vis absorption was monitored at $275 \mathrm{~nm}$.

\section{Synthesis of 2-(methyldisulfanyl)benzothia- zole (41)}

1,2-Bis(benzothiazol-2-yl)disulfane $(\mathbf{4 3}, 1.00 \mathrm{~g}, 3.00 \mathrm{mmol}$, 1 equiv) and dimethyl sulfide (44, $0.28 \mathrm{~g}, 3.00 \mathrm{mmol}, 1$ equiv) were dissolved in dry $\mathrm{CH}_{3} \mathrm{NO}_{2}(10 \mathrm{~mL})$ and dry $\mathrm{CH}_{2} \mathrm{Cl}_{2}$ $(10 \mathrm{~mL})$. The solution was cooled to $0{ }^{\circ} \mathrm{C}$ and then treated with $\mathrm{BF}_{3} \cdot \mathrm{Et}_{2} \mathrm{O}$ (43 mg, $0.3 \mathrm{mmol}, 0.1$ equiv). After stirring at $0{ }^{\circ} \mathrm{C}$ for 3 hours and at room temperature overnight, the reaction was 
quenched by the addition of water $(10 \mathrm{~mL})$ and extracted with ethyl acetate $(3 \times 50 \mathrm{~mL})$. The combined extracts were dried with $\mathrm{MgSO}_{4}$ and concentrated. The residue was purified by column chromatography (cyclohexane/ethyl acetate 1:1) to give 41 as a colorless solid $(0.82 \mathrm{~g}, 3.85 \mathrm{mmol}, 64 \%) . R_{\mathrm{f}} 0.60$ (cyclohexane/ethyl acetate 5:1; TLC visualized with UV illumination at $366 \mathrm{~nm}$ ); GC (HP-5MS): $I=1854$; IR (diamond-ATR) ṽ: 3060 (s), 2916 (s), 1425 (w), 1310 (s), 1236 (s), 1005 (w), $756(\mathrm{w}), 431(\mathrm{~s}) \mathrm{cm}^{-1} ;{ }^{1} \mathrm{H}$ NMR (500 MHz, $\left.\mathrm{CDCl}_{3}, 298 \mathrm{~K}\right) \delta$ $7.88(\mathrm{ddd}, J=8.1,1.2,0.7 \mathrm{~Hz}, 1 \mathrm{H}, \mathrm{CH}), 7.87(\mathrm{ddd}, J=7.9,1.2$, $0.6 \mathrm{~Hz}, 1 \mathrm{H}, \mathrm{CH}), 7.43(\mathrm{ddd}, J=8.3,7.3,1.2 \mathrm{~Hz}, 1 \mathrm{H}, \mathrm{CH}), 7.33$ (ddd, $J=8.2,7.2,1.2 \mathrm{~Hz}, 1 \mathrm{H}, \mathrm{CH}$ ), 2.67 (s, 3H, $\mathrm{CH}_{3}$ ) ppm; ${ }^{13} \mathrm{C}$ NMR (125 MHz, $\left.\mathrm{CDCl}_{3}, 298 \mathrm{~K}\right) \delta 172.50(\mathrm{C}), 155.17(\mathrm{C})$, $135.90(\mathrm{C}), 126.37(\mathrm{CH}), 124.70(\mathrm{CH}), 122.24(\mathrm{CH}), 121.27$ $(\mathrm{CH}), 23.62\left(\mathrm{CH}_{3}\right) \mathrm{ppm}$.

\section{Synthesis of ethyl (Z)-3-(methylsulfanyl)acry- late $((Z)-42)$ and ethyl $(E)-3-$ (methylsulfanyl)acrylate $((E)-\mathbf{4 2})$}

Ethyl propiolate $(\mathbf{4 5}, 70 \mathrm{mg}, 0.71 \mathrm{mmol}, 1$ equiv) was dissolved in distilled water $(5 \mathrm{~mL})$ followed by the addition of sodium methanethiolate (50 mg, $0.71 \mathrm{mmol}, 1$ equiv). The solution was stirred for 30 minutes at room temperature. Water $(5 \mathrm{~mL})$ was added and the product was extracted with ethyl acetate $(3 \times 10 \mathrm{~mL})$. The combined extracts were dried over $\mathrm{MgSO}_{4}$ and concentrated to afford the crude product. Purification by column chromatography (cyclohexane/ethyl acetate 99:1) gave a mixture of stereoisomers $(Z)-\mathbf{4 2}$ and $(E)-\mathbf{4 2}$ as pale yellow oil (96 mg, $0.65 \mathrm{mmol}, 92 \%$, dr $94: 6$ by ${ }^{1} \mathrm{H}$ NMR). The product mixture was separated by preparative HPLC to give pure (Z)-42 (73 mg, $0.50 \mathrm{mmol}, 70 \%)$ and $(E)-\mathbf{4 2}(6 \mathrm{mg}$, $0.04 \mathrm{mmol}, 6 \%)$.

(Z)-42. $R_{\mathrm{f}} 0.74$ (cyclohexane/ethyl acetate 1:1); GC (HP-5MS): $I=1200$; IR (diamond-ATR) ṽ: 2982 (w), 2927 (w),1695 (m), $1569(\mathrm{~m}), 1434$ (w), $1374(\mathrm{w}), 1300(\mathrm{w}), 1266(\mathrm{w}), 1213(\mathrm{~m})$, 1166 (s), 1095 (w), $1033(\mathrm{w}), 986(\mathrm{w}), 961(\mathrm{w}), 800(\mathrm{w}), 727$ (w), $687(\mathrm{w}) \mathrm{cm}^{-1} ;{ }^{1} \mathrm{H} \mathrm{NMR}\left(700 \mathrm{MHz}, \mathrm{CDCl}_{3}, 298 \mathrm{~K}\right) \delta 7.04$ (d, $J=10.14 \mathrm{~Hz}, 1 \mathrm{H}, \mathrm{CH}), 5.83(\mathrm{~d}, J=10.14 \mathrm{~Hz}, 1 \mathrm{H}, \mathrm{CH}), 4.20$ $\left(\mathrm{q}, J=7.15 \mathrm{~Hz}, 2 \mathrm{H}, \mathrm{CH}_{2}\right), 2.39\left(\mathrm{~s}, 3 \mathrm{H}, \mathrm{CH}_{3}\right), 1.29(\mathrm{t}, J=$ $\left.7.17 \mathrm{~Hz}, 3 \mathrm{H}, \mathrm{CH}_{3}\right) \mathrm{ppm} ;{ }^{13} \mathrm{C} \mathrm{NMR}\left(175 \mathrm{MHz}, \mathrm{CDCl}_{3}, 298 \mathrm{~K}\right) \delta$ $166.75(\mathrm{C}), 151.84(\mathrm{CH}), 113.18(\mathrm{CH}), 60.17\left(\mathrm{CH}_{2}\right), 19.28$ $\left(\mathrm{CH}_{3}\right), 14.44\left(\mathrm{CH}_{3}\right) \mathrm{ppm}$.

(E)-42. $R_{\mathrm{f}} 0.76$ (cyclohexane/ethyl acetate 1:1); GC (HP-5MS): $I=1177$; IR (diamond-ATR) ṽ: $2980(\mathrm{w}), 2925(\mathrm{w}), 1701$ (s), 1578 (s), 1444 (w), 1366 (w), 1322 (w), 1297 (m), 1251 (s), 1161 (s), 1095 (w), 1037 (m), 945 (m), 886 (w), 832 (w), 799 (w), $702(\mathrm{w}) \mathrm{cm}^{-1} ;{ }^{1} \mathrm{H} \mathrm{NMR}\left(700 \mathrm{MHz}, \mathrm{CDCl}_{3}, 298 \mathrm{~K}\right) \delta 7.76$ (d, $J=14.93 \mathrm{~Hz}, 1 \mathrm{H}, \mathrm{CH}), 5.68(\mathrm{~d}, J=14.90 \mathrm{~Hz}, 1 \mathrm{H}, \mathrm{CH}), 4.21$ $\left(\mathrm{q}, J=7.14 \mathrm{~Hz}, 2 \mathrm{H}, \mathrm{CH}_{2}\right), 2.35\left(\mathrm{~s}, 3 \mathrm{H}, \mathrm{CH}_{3}\right), 1.31(\mathrm{t}, J=$ $\left.7.13 \mathrm{~Hz}, 3 \mathrm{H}, \mathrm{CH}_{3}\right) \mathrm{ppm} ;{ }^{13} \mathrm{C} \mathrm{NMR}\left(175 \mathrm{MHz}, \mathrm{CDCl}_{3}, 297 \mathrm{~K}\right) \delta$ $165.59(\mathrm{C}), 147.21(\mathrm{CH}), 113.56(\mathrm{CH}), 60.55\left(\mathrm{CH}_{2}\right), 27.26$ $\left(\mathrm{CH}_{3}\right), 14.67\left(\mathrm{CH}_{3}\right) \mathrm{ppm}$.

\section{Supporting Information}

\section{Supporting Information File 1}

DMSP demethylation pathway in Celeribacter spp. and copies of spectra.

[https://www.beilstein-journals.org/bjoc/content/

supplementary/1860-5397-17-38-S1.pdf]

\section{Acknowledgements}

We thank Andreas Schneider (Bonn) for HPLC separation of (E)- and (Z)-42.

\section{Funding}

This work was funded by the Deutsche Forschungsgemeinschaft (DFG, German Research Foundation) - ProjectID 34509606 - TRR 51 within the frame of the Transregional Collaborative Research Center "Roseobacter".

\section{ORCID ${ }^{\circledR}$ iDs}

Jeroen S. Dickschat - https://orcid.org/0000-0002-0102-0631

\section{References}

1. Giovannoni, S. J.; Stingl, U. Nature 2005, 437, 343-348. doi:10.1038/nature04158

2. González, J. M.; Moran, M. A. Appl. Environ. Microbiol. 1997, 63, 4237-4242. doi:10.1128/aem.63.11.4237-4242.1997

3. Selje, N.; Simon, M.; Brinkhoff, T. Nature 2004, 427, 445-448. doi:10.1038/nature02272

4. Brinkhoff, T.; Giebel, H.-A.; Simon, M. Arch. Microbiol. 2008, 189, 531-539. doi:10.1007/s00203-008-0353-y

5. Lee, O. O.; Tsoi, M. M. Y.; Li, X.; Wong, P.-K.; Qian, P.-Y. Int. J. Syst. Evol. Microbiol. 2007, 57, 1919-1924. doi:10.1099/ijs.0.64801-0

6. Ruiz-Ponte, C.; Cilia, V.; Lambert, C.; Nicolas, J. L. Int. J. Syst. Bacteriol. 1998, 48, 537-542. doi:10.1099/00207713-48-2-537

7. Shiba, T. Syst. Appl. Microbiol. 1991, 14, 140-145. doi:10.1016/s0723-2020(11)80292-4

8. Biebl, H.; Allgaier, M.; Tindall, B. J.; Koblizek, M.; Lünsdorf, H.; Pukall, R.; Wagner-Döbler, I. Int. J. Syst. Evol. Microbiol. 2005, 55 , 1089-1096. doi:10.1099/ijs.0.63511-0

9. Lafay, B.; Ruimy, R.; Rausch de Traubenberg, C.; Breittmayer, V.; Gauthier, M. J.; Christen, R. Int. J. Syst. Bacteriol. 1995, 45, 290-296. doi:10.1099/00207713-45-2-290

10. Gonzalez, J. M.; Simo, R.; Massana, R.; Covert, J. S.; Casamayor, E. O.; Pedros-Alio, C.; Moran, M. A. Appl. Environ. Microbiol. 2000, 66, 4237-4246. doi:10.1128/aem.66.10.4237-4246.2000 
11. Dickschat, J. S.; Rabe, P.; Citron, C. A. Org. Biomol. Chem. 2015, 13, 1954-1968. doi:10.1039/c4ob02407a

12. Reisch, C. R.; Stoudemayer, M. J.; Varaljay, V. A.; Amster, I. J.; Moran, M. A.; Whitman, W. B. Nature 2011, 473, 208-211. doi:10.1038/nature10078

13. Todd, J. D.; Rogers, R.; Li, Y. G.; Wexler, M.; Bond, P. L.; Sun, L.; Curson, A. R. J.; Malin, G.; Steinke, M.; Johnston, A. W. B. Science 2007, 315, 666-669. doi:10.1126/science.1135370

14. Todd, J. D.; Kirkwood, M.; Newton-Payne, S.; Johnston, A. W. B. ISME J. 2012, 6, 223-226. doi:10.1038/ismej.2011.79

15. Kirkwood, M.; Le Brun, N. E.; Todd, J. D.; Johnston, A. W. B. Microbiology (London, U. K.) 2010, 156, 1900-1906. doi:10.1099/mic.0.038927-0

16. Todd, J. D.; Curson, A. R. J.; Kirkwood, M.; Sullivan, M. J.; Green, R. T.; Johnston, A. W. B. Environ. Microbiol. 2011, 13, 427-438. doi:10.1111/j.1462-2920.2010.02348.x

17. Curson, A. R. J.; Rogers, R.; Todd, J. D.; Brearley, C. A.; Johnston, A. W. B. Environ. Microbiol. 2008, 10, 757-767. doi:10.1111/j.1462-2920.2007.01499.x

18. Curson, A. R. J.; Sullivan, M. J.; Todd, J. D.; Johnston, A. W. B. ISME J. 2011, 5, 1191-1200. doi:10.1038/ismej.2010.203

19. Sun, J.; Todd, J. D.; Thrash, J. C.; Qian, Y.; Qian, M. C.; Temperton, B.; Guo, J.; Fowler, E. K.; Aldrich, J. T.; Nicora, C. D.; Lipton, M. S.; Smith, R. D.; De Leenheer, P.; Payne, S. H.; Johnston, A. W. B.; Davie-Martin, C. L.; Halsey, K. H.; Giovannoni, S. J. Nat. Microbiol. 2016, 1, 16065. doi:10.1038/nmicrobiol.2016.65

20. Lovelock, J. E.; Maggs, R. J.; Rasmussen, R. A. Nature 1972, 237 452-453. doi:10.1038/237452a0

21. Charlson, R. J.; Lovelock, J. E.; Andreae, M. O.; Warren, S. G. Nature 1987, 326, 655-661. doi:10.1038/326655a0

22. Dickschat, J. S.; Zell, C.; Brock, N. L. ChemBioChem 2010, 11, 417-425. doi:10.1002/cbic.200900668

23. Brock, N. L.; Citron, C. A.; Zell, C.; Berger, M.; Wagner-Döbler, I.; Petersen, J.; Brinkhoff, T.; Simon, M.; Dickschat, J. S. Beilstein J. Org. Chem. 2013, 9, 942-950. doi:10.3762/bjoc.9.108

24. Brock, N. L.; Menke, M.; Klapschinski, T. A.; Dickschat, J. S. Org. Biomol. Chem. 2014, 12, 4318-4323. doi:10.1039/c4ob00719k

25. Celik, E.; Maczka, M.; Bergen, N.; Brinkhoff, T.; Schulz, S.; Dickschat, J. S. Org. Biomol. Chem. 2017, 15, 2919-2922. doi:10.1039/c7ob00357a

26. Durham, B. P.; Sharma, S.; Luo, H.; Smith, C. B.; Amin, S. A.; Bender, S. J.; Dearth, S. P.; Van Mooy, B. A. S.; Campagna, S. R.; Kujawinski, E. B.; Armbrust, E. V.; Moran, M. A.

Proc. Natl. Acad. Sci. U. S. A. 2015, 112, 453-457. doi:10.1073/pnas.1413137112

27. Mönnich, J.; Tebben, J.; Bergemann, J.; Case, R.; Wohlrab, S.; Harder, T. ISME J. 2020, 14, 1614-1625. doi:10.1038/s41396-020-0631-5

28. Bruhn, J. B.; Nielsen, K. F.; Hjelm, M.; Hansen, M.; Bresciani, J.; Schulz, S.; Gram, L. Appl. Environ. Microbiol. 2005, 71, 7263-7270. doi:10.1128/aem.71.11.7263-7270.2005

29. Greer, E. M.; Aebisher, D.; Greer, A.; Bentley, R. J. Org. Chem. 2008, 73, 280-283. doi:10.1021/jo7018416

30. Kintaka, K.; Ono, H.; Tsubotani, S.; Harada, S.; Okazaki, H. J. Antibiot 1984, 37, 1294-1300. doi:10.7164/antibiotics.37.1294

31. Geng, H.; Bruhn, J. B.; Nielsen, K. F.; Gram, L.; Belas, R. Appl. Environ. Microbiol. 2008, 74, 1535-1545. doi:10.1128/aem.02339-07
32. Berger, M.; Brock, N. L.; Liesegang, H.; Dogs, M.; Preuth, I.; Simon, M.; Dickschat, J. S.; Brinkhoff, T. Appl. Environ. Microbiol. 2012, 78, 3539-3551. doi:10.1128/aem.07657-11

33. Brock, N. L.; Nikolay, A.; Dickschat, J. S. Chem. Commun. 2014, 50, 5487-5489. doi:10.1039/c4cc01924e

34. Beyersmann, P. G.; Tomasch, J.; Son, K.; Stocker, R.; Göker, M.; Wagner-Döbler, I.; Simon, M.; Brinkhoff, T. Sci. Rep. 2017, 7, 730. doi:10.1038/s41598-017-00784-7

35. Thiel, V.; Brinkhoff, T.; Dickschat, J. S.; Wickel, S.; Grunenberg, J.; Wagner-Döbler, I.; Simon, M.; Schulz, S. Org. Biomol. Chem. 2010, 8, 234-246. doi:10.1039/b909133e

36. Seyedsayamdost, M. R.; Case, R. J.; Kolter, R.; Clardy, J. Nat. Chem. 2011, 3, 331-335. doi:10.1038/nchem.1002

37. Grob, K.; Zürcher, F. J. Chromatogr. 1976, 117, 285-294. doi:10.1016/0021-9673(76)80005-2

38. Kováts, E. Helv. Chim. Acta 1958, 41, 1915-1932. doi:10.1002/hlca.19580410703

39. Elmore, J. S.; Mottram, D. S.; Enser, M.; Wood, J. D. Meat Sci. 2000, 55, 149-159. doi:10.1016/s0309-1740(99)00137-0

40. Dickschat, J. S.; Wickel, S.; Bolten, C. J.; Nawrath, T.; Schulz, S.; Wittmann, C. Eur. J. Org. Chem. 2010, 2687-2695. doi:10.1002/ejoc.201000155

41. Cerny, C.; Guntz-Dubini, R. J. Agric. Food Chem. 2006, 54, 574-577. doi:10.1021/jf052222s

42. Spadone, J.-C.; Takeoka, G.; Liardon, R. J. Agric. Food Chem. 1990, 38, 226-233. doi:10.1021/jf00091a050

43. Lee, S.-R.; Macku, C.; Shibamoto, T. J. Agric. Food Chem. 1991, 39 , 1972-1975. doi:10.1021/jf00011a017

44. Pino, J. A.; Mesa, J.; Muñoz, Y.; Martí, M. P.; Marbot, R. J. Agric. Food Chem. 2005, 53, 2213-2223. doi:10.1021/jf0402633

45. Adams, R. P. Identification of Essential Oil Components by Gas Chromatography Mass Spectrometry; Allured Pub Corp.: Carol Stream, IL, 2009.

46. Ansorena, D.; Gimeno, O.; Astiasarán, I.; Bello, J. Food Res. Int. 2001, 34, 67-75. doi:10.1016/s0963-9969(00)00133-2

47. Citron, C. A.; Rabe, P.; Dickschat, J. S. J. Nat. Prod. 2012, 75 , 1765-1776. doi:10.1021/np300468h

48. Owens, J. D.; Allagheny, N.; Kipping, G.; Ames, J. M. J. Sci. Food Agric. 1997, 74, 132-140. doi:10.1002/(sici)1097-0010(199705)74:1<132::aid-jsfa779>3.0.co;2-8

49. Cha, Y. J.; Cadwallader, K. R. J. Agric. Food Chem. 1998, 46 , 1123-1128. doi:10.1021/jf970380g

50. Wickel, S. M.; Citron, C. A.; Dickschat, J. S. Eur. J. Org. Chem. 2013, 2906-2913. doi:10.1002/ejoc.201300049

51. Kubec, R.; Drhová, V.; Velíšek, J. J. Agric. Food Chem. 1998, 46 , 4334-4340. doi:10.1021/jf980379x

52. Ferhat, M. A.; Tigrine-Kordjani, N.; Chemat, S.; Meklati, B. Y.; Chemat, F. Chromatographia 2007, 65, 217-222. doi:10.1365/s10337-006-0130-5

53. Takeoka, G. R.; Buttery, R. G.; Teranishi, R.; Flath, R. A.; Güntert, M. J. Agric. Food Chem. 1991, 39, 1848-1851. doi:10.1021/jf00010a032

54. Nawrath, T.; Mgode, G. F.; Weetjens, B.; Kaufmann, S. H. E.; Schulz, S. Beilstein J. Org. Chem. 2012, 8, 290-299. doi:10.3762/bjoc.8.31

55. Citron, C. A.; Barra, L.; Wink, J.; Dickschat, J. S. Org. Biomol. Chem. 2015, 13, 2673-2683. doi:10.1039/c4ob02609h

56. Schulz, S.; Dickschat, J. S. Nat. Prod. Rep. 2007, 24, 814-842. doi:10.1039/b507392h

57. Dickschat, J. S. Nat. Prod. Rep. 2017, 34, 310-328. doi:10.1039/c7np00003k 
58. Ueda, D.; Matsugane, S.; Okamoto, W.; Hashimoto, M.; Sato, T. Angew. Chem., Int. Ed. 2018, 57, 10347-10351.

doi:10.1002/anie.201805383

59. Werz, D. B.; Staeb, T. H.; Benisch, C.; Rausch, B. J.; Rominger, F.; Gleiter, R. Org. Lett. 2002, 4, 339-342. doi:10.1021/ol016953z

60. Leverett, C. A.; Purohit, V. C.; Romo, D. Angew. Chem., Int. Ed. 2010, 49, 9479-9483. doi:10.1002/anie.201004671

61. Dickschat, J. S. Nat. Prod. Rep. 2014, 31, 838-861. doi:10.1039/c3np70080a

62. Takeoka, G. R.; Buttery, R. G.; Flath, R. A. J. Agric. Food Chem. 1992, 40, 1925-1929. doi:10.1021/jf00022a040

63. Werkhoff, P.; Güntert, M.; Krammer, G.; Sommer, H.; Kaulen, J. J. Agric. Food Chem. 1998, 46, 1076-1093. doi:10.1021/jf970655s

64. Ferreira, L.; Perestrelo, R.; Caldeira, M.; Câmara, J. S. J. Sep. Sci. 2009, 32, 1875-1888. doi:10.1002/jssc.200900024

65. Fulmer, G. R.; Miller, A. J. M.; Sherden, N. H.; Gottlieb, H. E.; Nudelman, A.; Stoltz, B. M.; Bercaw, J. E.; Goldberg, K. I.

Organometallics 2010, 29, 2176-2179. doi:10.1021/om100106e

\section{License and Terms}

This is an Open Access article under the terms of the Creative Commons Attribution License (https://creativecommons.org/licenses/by/4.0). Please note that the reuse, redistribution and reproduction in particular requires that the author(s) and source are credited and that individual graphics may be subject to special legal provisions.

The license is subject to the Beilstein Journal of Organic Chemistry terms and conditions:

(https://www.beilstein-journals.org/bjoc/terms)

The definitive version of this article is the electronic one which can be found at: https://doi.org/10.3762/bjoc. 17.38 